\title{
И.А. Пильщиков
}

Университет Калифорнии, Лос-Анджелес, 90095 г. Лос-Анджелес, США;

Московский государственный университет им. М.В. Ломоносова, 119899 г. Москва, Российская Федерация;

Таллинский университет, 10120 г. Таллин, Эстония

\section{Пражская школа}

на «перекрестке культур»

(О многоязычии

в научной переписке и изданиях Пражского лингвистического кружка)

В статье обсуждается многоязычная научная переписка Пражского лингвистического кружка в связи с типологией научных объединений и ситуацией «культурного полиглотизма» Пражской школы. Предложены дополнения к историко-научному комментарию академического издания «Pražská škola v korespondenci: Dopisy z let 1924-1989» (Prague: Karolinum, 2014). Ocoбoe внимание уделено чехословацким страницам биографии Р.О. Якобсона.

Ключевые слова: Пражская школа, Пражский лингвистический кружок, история филологии, научный быт, бытовое многоязычие и культурный полиглотизм, P.О. Якобсон

ДЛЯ ЦИТИРОВАНИЯ: Пильщиков И.А. Пражская школа на «перекрестке культур» (О многоязычии в научной переписке и изданиях Пражского лингвистического кружка) // Рема. Rhema. 2019. № 3. C. 25-52. DOI: 10.31862/25002953-2019-3-25-52 


\section{Pilshchikov}

University of California, Los Angeles (UCLA),

Los Angeles, CA, 90095, USA;

Lomonosov Moscow State University,

Moscow, 119899, Russian Federation;

Tallinn University,

Tallinn, 10120, Estonia

\section{The Prague School}

at the "Crossroads of Cultures"

(On Multilingualism in the Correspondence of the Prague Linguistic Circle)

The article discusses the multilingual correspondence of the Prague Linguistic Circle in connection with the typology of scholarly associations, on the one hand, and "cultural polyglottism" of the Prague School, on the other. The author provides addenda to the academic edition Pražská škola v korespondenci: Dopisy z let 1924-1989 (Prague: Karolinum, 2014). Special attention is paid to Roman Jakobson's Czechoslovak years.

Key words: Prague School, Prague Linguistic Circle, intellectual history, the socialenvironmental aspect of research, multilingualism and cultural polyglottism, Roman Jakobson

FOR CITATION: Pilshchikov I.A. The Prague School at the "Crossroads of Cultures" (On multilingualism in the correspondence of the Prague Linguistic Circle). Rhema. 2019. No. 3. Pp. 25-52. DOI: 10.31862/2500-2953-2019-3-25-52

В 1975 г. Вяч.Вс. Иванов, анализируя типологию научных объединений в связи с собственным опытом участника Тартуско-московской семиотической школы, противопоставил социально успешный проект Пражского лингвистического кружка (ПЛК, 1926-1952) вынужденному герметизму одного из его непосредственных предшественников Московского лингвистического кружка (МЛК, 1915-1924): «Необходимым условием плодотворности периодических встреч научной группы, 
участники которой обычно (вне этих встреч) пространственно разобщены, является предварительное размножение обширных письменных тезисов основных выступлений, как это показывает, в частности, опыт летних школ по семиотике, организуемых проф. Ю.М. Лотманом в Тарту с 1964 г. Письменная фиксация предварительных результатов работы... превращает их в реальный факт международного (заочного) научного общения <...>. Необходимость такой фиксации результатов... становится очевидной при сравнении широко известных изданий Пражского лингвистического кружка с теми чрезвычайно важными для истории современной лингвистики опытами, которые предшествовали работе этого кружка, но по типографским условиям того времени не были зафиксированы в печати, недостаточно отражены и в архивных рукописных материалах и в настоящее время реконструируются лишь по неполным данным» [Иванов, 1975, с. 4].

Иванов развивает здесь наблюдения одного из главных очевидцев описываемых событий, оказавшегося в числе ключевых инициаторов ПЛК и МЛК. Это Роман Якобсон, который писал о московском кружке: «В связи с техническими трудностями того времени многое из его литературных заготовок долго ждало сдачи в печать и частью оказалось утрачено. Устная передача была главным путем распространения научной мысли молодого сотоварищества. В 1926 г. организационная модель МЛК заодно с его научными планами и достижениями легла в основу новоучрежденного Пражского Лингвистического Кружка, существенно двинувшего вперед и широко развернувшего работу своего предтечи, с которым его связывал также ряд общих сотрудников, частью постоянных, частью кратковременных гостей. Интенсивная печатная деятельность и тесное личное общение с международным научным миром способствовало далекому распространению и обмену плодоносных идей в лингвистике, поэтике и сродных науках» [Якобсон, 1996, с. 368] (ср.: [Jakobson, 1971, p. 533-535]). Изучение русского формализма и пражского структурализма как научных сообществ, как генераторов новых стратегий научного мышления и форм научного общения обращает наше внимание на сам феномен «кружка». Недаром в своей первой ретроспективной англоязычной статье про МЛК [Jakobson, 1971] Якобсон нередко оставляет без перевода русское kružok и чешское kroužek [Гланц, Пильщиков, 2017, с. 88-91].

Хотя, в отличие от МЛК, Пражский кружок имел возможность реализовать свои научные планы и исследовательские программы в печатных работах, объем материала, оставшегося неопубликованным, чрезвычайно велик. Введение в научный оборот архивных документов, долгое время остававшихся известными лишь узкому кругу 
исследователей, имеет большое историко-научное значение. Для дальнейшего осмысления и развития научного наследия ПЛК могут пригодиться как данные, относящиеся к истории науки, так и данные, относящиеся к сфере «научного быта» ${ }^{1}$. По замечанию именитого исследователя центральноевропейского структурализма, «история любой науки не может опираться исключительно на внутреннее развитие, она неотделима как от внешних событий, так и от философских убеждений и идеологических представлений, разделяемых учеными» [Sériot, 1997, p. 345]. В 2012 г. произошло значительное эдиционное событие: были опубликованы протоколы заседаний и иных документов ПЛК [Čermák, Poeta, Čermák, 2012]. Затем настала очередь объединить под одной обложкой частную и рабочую корреспонденцию членов кружка.

В книге «Пражская школа в корреспонденции» [Havránková, Petkevič, $2014]^{2}$ опубликовано 582 письма 55 лингвистов - это письма членов ПЛК друг другу, а также письма лингвистов других школ членам ПЛК и Кружку в целом. Письма расположены секциями в алфавитном порядке адресантов, а внутри каждой секции - по адресатам. Внутри группы писем к одному адресату письма расположены хронологически. Иногда в секцию включаются иные тематически и хронологически связанные письма. Во многих случаях в секцию, помимо писем «заглавного» героя, включаются и письма к нему - в результате некоторые персонажи остались без «собственной» секции, будучи включены в «чужие». Структура сборника, на первый взгляд не слишком наглядная, постепенно проясняется по мере работы с книгой. Читатель, желающий найти определенную группу писем, должен искать их либо по адресату, либо по адресанту: заранее сказать, как именно классифицировано конкретное письмо, нельзя.

Не использованы в качестве классифицирующих персоналий имена основателей ПЛК Вилема Матезиуса и Романа Якобсона, хотя в сборнике опубликованы большие блоки писем Матезиуса к младшим коллегам (Йозефу Вахеку и Рене Веллеку) и большие блоки писем Якобсона к Николаю Дурново, Отокару Фишеру, Витезславу Незвалу, Ярославу Сейферту и Йозефу Вахеку, а также одно письмо Якобсона к Дмитрию Чижевскому и одно его письмо к Антонину Станиславу Магру, которое составляет отдельную магровскую секцию в разделе «Внутренний круг Пражской школы» («Vnitřní okruh Pražské školy») ${ }^{3}$. Письма Матезиуса

\footnotetext{
${ }^{1}$ Термин образован по аналогии с эйхенбаумовским «литературный быт» [Эйхенбаум, 1927].

2 Далее ссылки на это издание даются в тексте статьи.

${ }^{3}$ Формально А.С. Магр не был членом Кружка, и в преамбуле к посвященной ему секции он назван «приверженцем ПЛК» («p̌ŕíznivec PLK») (c. 220; cp. [Čermák, Poeta, Čermák, 2012, p. 395]).
} 
и Якобсона к Альфреду Бему напечатаны в бемовской секции. Богуслав Гавранек и Богумил Трнка присутствуют в книге главным образом в качестве адресатов писем от коллег - исключение составляет переписка Трнки с Вахеком, где за письмом Вахека Трнке от 1933 г. следует 22 письма Трнки Вахеку за 1946-1982 гг., а также обмен письмами между Трнкой и Джакомо Девото (по одному письму от каждого).

Деловая переписка членов ПЛК с «внешним кругом Пражской школы», составившая второй раздел сборника, впечатляет самим набором имен корреспондентов: Шарль Балли, Эмиль Бенвенист, Леонард Блумфилд, Карл Бюлер, Жозеф Вандриес, Луи Ельмслев, Отто Есперсен, Антуан Мейе, Эдвард Сепир, Люсьен Теньер, Макс Фасмер и другие выдающиеся лингвисты. Третий раздел составляют поздравительные письма лингвистов мира в связи с 10-летним юбилеем ПЛК (1936) - еще одно наглядное свидетельство влияния Пражской школы на современников.

Некоторые вошедшие в книгу письма уже публиковались, значительная часть печатается впервые. В редакторской справке (с. 753, примеч. 1 и 2) перечислены основные издания, в которых ранее печатались отдельные письма, а сведения о предыдущих публикациях каждого конкретного письма включены в комментарий к соответствующему письму. В настоящей работе предлагаются дополнения к историко-научному комментарию обсуждаемого издания ${ }^{4}$.

Межвоенная Прага была одним из локусов, открытых для межкультурных контактов, «свободным рынком идей» [Steiner, 1982, p. 179] или «“контактной зоной”, где происходил обмен культурными товарами» (“а 'contact zone' where cultural goods were exchanged”) [Greenblatt, 2009 , p. 251]. Прага - обломок Австро-Венгерской империи, ставший центром строительства новой культурной и политической идентичности Центральной Европы и убежищем для эмигрантов из распавшейся Российской империи [Toman, 1995, p. 103-134], - дала новую жизнь теории языка, литературы и культуры. По словам Галина Тиханова, рождавшаяся на глазах современников Центральная Европа «развивалась на стыке национального энтузиазма и культурного космополитизма, выходящего за рамки местной инкапсуляции и моноглоссии» [Tihanov, 2004, p. 67] ${ }^{5}$. Отсылая к концепции «travelling theory» Эдварда Саида [Said, 2000], Тиханов отмечает «огромную важность изгнания и эмиграции для рождения современной литературной теории в Восточной

\footnotetext{
${ }^{4}$ Некоторые соображения были уже высказаны в моей рецензионной статье [Pilščikov, 2015].

${ }^{5}$ «...developed at the intersection between national enthusiasms and a cultural cosmopolitanism that transcended local encapsulation and monoglossia». В этом абзаце и далее все переводы мои.
} 
и Центральной Европе» [Tihanov, 2004, p. 68]. О том же, но с точки зрения теории «культурных ареалов», сформировавшейся под влиянием теории «языковых союзов» Якобсона-Трубецкого, писал Ю.М. Лотман в неопубликованной статье «Некоторые проблемы сравнительного изучения художественных текстов» (1971-1972): «Совокупность культур с определенными общими кодами образует культурный ареал. Внутриареальный обмен всегда бывает более интенсивным. Для компаративных исследований в этом отношении особый интерес представляют те географические районы, где разного типа культуры длительное время сосуществовали, находясь в тесном пространственном общении. Примерами таких районов будут Закавказье, Прибалтика, Средиземноморье, Центральная Европа» 6 .

В статье «О предпосылках Пражской лингвистической школы» Якобсон утверждал, что «Чехословакия лежит на перекрестке различных культур» («Československo leží na rozcestí rozličných kultur»), a Пражскую школу называл «плодом симбиоза чешской и русской мысли» [Jakobson, 1934, p. 8], умолчав (очевидно, по политическим причинам) об участии в этом симбиозе еще одной национальной школы мысли немецкой. Ср. более широкий контекст первой цитаты: «Оригинальность школы проявляется в выборе новых идей и в их соединении в систематическое целое. Чехословакия лежит на перекрестке различных культур, и историческое своеобразие ее культуры с глубокой древности... заключается именно в творческом соединении потоков, льющихся из отдаленных источников» (пер. О.М. Малевича) [Цит. по: Малевич, 2007, с. 105]. В статье «Význam ruské filologie pro bohemistiku» («Значение русской филологии для богемистики», 1938) Якобсон отнес к тому же типу культур русскую: «Если мы сравним историю культуры двунаправленных славянских целых, т.е. русскую и чешскую, с историей культуры однонаправленных славянских целых, то придем к убеждению, что, собственно, только двунаправленные целые создают культурные течения, отличающиеся значительными экспортными ценностями» [Цит. по: Малевич, 2007, с. 114] (см. также [Малевич, 1993, с. 79]). О самоорганизации славистики как «планомерно организованном культурном экспорте», требующем «изучения рынка культурного сбыта», Якобсон пишет по-немецки в статье «Über die heutigen Voraussetzungen der russischen Slavistik» («O современных предпосылках русской славистики», 1929), которая обсуждается ниже (перевод цитаты: [Гаспаров, Автономова, 1999, с. 335]).

Сказанное Якобсоном применимо не только к концептуальному и культурному, но и к бытовому многоязычию. Пражский лингвистический

\footnotetext{
${ }^{6}$ Tallinna Ülikool. Juri Lotmani semiootikavaramu. Ф. 1 (Ю.М. Лотман). Ед. хр. б/н. Л. 16.
} 
кружок был мультикультурным и интернациональным феноменом, объединяющим чешских, словацких, русских и немецких ученых, которые внесли значительный вклад в его становление и развитие. Переписка между членами ПЛК и их коллегами велась на шести языках: чешском, словацком, русском, немецком, французском и английском ${ }^{7}$. Иногда язык той или иной группы писем трудно предугадать заранее. Так, Богуславу Гавранку Петр Богатырев и Сергей Карцевский писали по-русски, Дмитрий Чижевский и Николай Трубецкой - по-немецки, Александр Исаченко - в основном по-словацки (хотя несколько писем написаны по-чешски), Людовит Новак - наоборот, в основном по-чешски (хотя несколько писем написаны по-словацки), Ойген Риппль - тоже в основном по-чешски (хотя одно письмо написано по-немецки), а Хенрик Беккер - по-немецки с приписками по-чешски. Датчанин Вигго Брёндаль писал Трнке по-французски и по-английски, а Гавранку по-французски и по-немецки. Итальянец Джакомо Девото переписывался с Трнкой по-немецки, а письмо Гавранку написал по-французски. Голландец Альберт Виллем де Гроот и датчанин Луи Ельмслев переписывались с членами Кружка на трех языках: немецком, французском и английском (при этом письмо Ельмслева от 20 января 1939 г. с выражением признательности за прием в члены ПЛК написано - вероятно, с чьей-то помощью - по-чешски). В сборнике все письма печатаются как на языке оригинала, так и в переводе на чешский.

Обсуждаемое издание весьма полезно для историков чешской, словацкой, немецкой и русской науки (в последнем случае - как российской, так и эмигрантской). Более того, сам представленный в сборнике материал ярко демонстрирует возможность меж- и наднациональной (ре)интерпретации истории гуманитарных наук в духе «cultural mobility studies» [Greenblatt, 2009] и/или «histoire croisée» [Werner, Zimmermann, 2006; Haupt, Kocka, 2010]. Различные ветви структурализма в межвоенной и послевоенной Центральной и Восточной Европе продолжали и «сплетали» линии развития, ведущие как от немецкого и русского формализма, так и от национальных эстетических традиций [Steiner, 1982; Тиханов, 2002; Tihanov, 2004; Tihanov, 2019]. Это позволяет говорить об общеевропейском и даже мировом структуралистском движении, характеризовавшемся сложным динамическим единством в разнообразии своих национальных вариантов [Pilshchikov, Trunin, 2016].

Русскоязычная часть переписки ПЛК была частично опубликована ранее в издании Йиндржиха Томана [Toman, 1994]. Среди этих писем особую ценность представляет письмо к Якобсону географа-евразийца

\footnotetext{
${ }^{7}$ О языковой ситуации внутри ПЛК см. [Ehlers, 2005, p. 414-430].
} 
Петра Николаевича Савицкого, чье влияние на других «русских пражцев» часто недооценивается [Toman, 1995, p. 115-116, 214-215; Серио, 1999]. С Савицким, как и с другим лидером евразийцев, князем Николаем Сергеевичем Трубецким, Якобсон был близок интеллектуально и биографически. Более того, 16 октября 1938 г. (по юлианскому календарю) Савицкий стал крестным отцом Якобсона, перешедшего из иудаизма в православие [Ба́ран, 2017, с. 453]. С евразийством идеологически и отчасти научно связана программная статья Якобсона «Über die heutigen Voraussetzungen der russischen Slavistik» («O современных предпосылках русской славистики»), опубликованная в октябрьском номере пражско-берлинского «Славянского обозрения» за 1929 г. [Гаспаров, Автономова, 1999; Автономова, 2009, с. 43-52]. Периодическое издание «Slavische Rundschau: Berichtende und kritische Zeitschrift für das geistige Leben der slavischen Völker» («Славянское обозрение: Информационнокритический журнал о духовной жизни славянских народов») выпускалось издательством «Walter de Gruyter» (Берлин - Лейпциг - Прага) и выходило на немецком языке в Праге с 1929 г. по 1940 г., после чего было закрыто нацистами. Главными редакторами были профессора Немецкого университета в Праге Франц Спина и Герхард Геземанн. До 1938 г. Якобсон руководил восточнославянской секцией журнала. O «Slavische Rundschau» и участии в нем Якобсона и других русских пражцев см.: [Автономова, 2009, с. 59-74; Марченко, 2016].

Необходимо небольшое уточнение к статье Т.В. Марченко, которая пишет в связи со статьей Якобсона «О поколении, растратившем своих поэтов», впервые напечатанной в сокращении по-немецки в «Slavische Rundschau» (1930. № 7): «Von einer Generation, die ihre Dichter vergeudet hat. S. 481-495. Каноническое название этой работы не кажется удачным - лучше было бы "растранжирившем" (с отсылкой к Маяковскому же - “бесценных слов мот и транжир”, “Нате”). Кстати, именно это и означает немецкий глагол “vergeuden”» [Марченко, 2016, с. 153, примеч. 4]. Замечание не лишено проницательности, однако каноническое название этой работы принадлежит самому Якобсону, который написал статью по-русски и опубликовал полный оригинальный текст в составе книги «Смерть Владимира Маяковского» (Берлин, 1931). В письме к Хью МакЛейну от 1 октября 1976 г. Якобсон вспоминал: «Гибель Маяковского меня до костей потрясла неожиданным осуществлением издавна предвиденного. <..> Было долгом сказать о промотавшемся поколении ${ }^{8}$, и я писал, наглухо запершись на несколько дней, писал без

\footnotetext{
${ }^{8}$ Отсылка к «Думе» Лермонтова («Печально я гляжу на наше поколенье!..») с его заключительными строками: Насмешкой горькою обманутого сына / Над промотавшимся отиом.
} 
отрыва. Окончив, позвал русских друзей, живших или бывших проездом в Праге, прочел им написанное, ошеломил и Бема, и Гессена, и Савицкого, и Чижевского, и первым прервавший общее молчание Богатырев крикнул: “Ты никогда ничего сильнее и глубже не напишешь!” Так же отозвался Илья Эренбург, получив машинописную копию. Сокращенный немецкий перевод, сделанный Гектером (Hekter), украинцем, работавшим в "Prager Presse" и "Slavische Rundschau", был напечатан в этом журнале» [Цит. по: Гиндин, 1999, с. 165]. Разослав русским филологам-эмигрантам письма с просьбой написать о Маяковском, Якобсон сумел собрать лишь «двухстатейный сборничек» [Там же]. Не отозвался никто, кроме Д. Святополк-Мирского: слишком одиозной была репутация Маяковского как сторонника большевизма. Вместе с тем публикация книги отрезала Якобсону путь в Советскую Россию (Мирский, вернувшийся в СССР в 1932 г., погиб в ГУЛАГе в 1939 г.) [Гиндин, 1999; Ustinov, 2018].

От евразийства в якобсоновских работах этого периода - внимание к лингвистической географии, изучение общих черт между русским и соседними неиндоевропейскими языками и культурами [Серио, 1999; Автономова, 2009, с. 74-90]. Для описания такой общности Якобсон и Трубецкой ввели понятие «языковой союз» (Sprachbund) - структурно-функциональное единство неродственных языков, возникающее вследствие долговременных географических контактов и принципиально отличающееся от понятия «языковой семьи» в сравнительно-историческом языкознании. Таким образом, исследователи предложили в дополнение к историческому (генетическому) подходу к классификации языков пространственный (ареальный); первый подход описывает процесс дивергенции языков, второй - процесс конвергенции. В работе «К характеристике евразийского языкового союза» (1931) Якобсон выделяет общий лингвистический признак, объединяющий языки Евразии, - наличие пар непалатализованных и палатализованных («твердых» и «мягких») согласных [Якобсон, 1931]. Специальную статью «О фонологических языковых союзах» Якобсон напечатал по-немецки в четвертом выпуске «Трудов Пражского лингвистического кружка» («Travaux du Cercle linguistique de Prague», 1931) и по-русски в евразийском сборнике «Евразия в свете языкознания» (Прага, 1931).

Письмо Савицкого Якобсону (№ 237 в общей нумерации писем «Пражской школы в корреспонденции») написано 9-10 августа 1930 г. по прочтении рукописи вышеупомянутой работы «К характеристике евразийского языкового союза». Комментарий к письму и его текстология требуют некоторых дополнений и поправок. Под «предыдущим письмом», на которое ссылается Савицкий (с. 291), следует понимать его неопубликованное письмо от 7 августа 1930 г., в котором он излагал 
Якобсону свои мысли о «россиеведении» как систематической науке и вспоминал о том, как в 1919 г. в тифозном бреду придумал использовать слово «Евразия» для обозначения Pax Rossica [Sériot, 1999, p. 63, 265$]^{9}$. В перечне терминологических образований Савицкого имеется опечатка (или неисправленная и непрокомментированная описка), перешедшая в обсуждаемый сборник из издания Й. Томана [Toman, 1994, p. 128]. Я имею в виду причастие «азиазизированный» (с. 292) вместо «азиатизированный (язык)». Причастие образовано от (приведенного там же) глагола «азиатизировать» - ср. с (приведенным там же) существительным «азиатизация (языка)».

Можно пожалеть, что в пражский сборник не включены другие письма Савицкого Якобсону, хранящиеся в архиве Якобсона в Массачусетском технологическом институте (MIT), - они еще ждут своего издателя ${ }^{10}$. Не вполне понятно также, почему в сборник не включены чешскоязычные письма Якобсона Трнке за 1935-1938 гг., содержащие, по характеристике их первого публикатора, «материалы, связанные с поденной работой кружка» («materials relating to the Circle's everyday operation») [Там же, p. 168], при том что опубликованные в издании Томана письма Якобсона к другим членам ПЛК - Николаю Дурново и Альфреду Бему (по-русски), Отокару Фишеру (по-чешски) и члену-корреспонденту ПЛК Дмитрию Чижевскому (по-русски) - включены в обсуждаемое издание в полном объеме ${ }^{11}$.

Отдельного разговора заслуживает переписка Трубецкого и Якобсона (между собой они переписывались по-русски). Письма Якобсона были изъяты гестаповцами при аресте Трубецкого и пропали; сохранилось только несколько писем, копии которых оставил у себя их автор. Письма Трубецкого Якобсону издал сам Якобсон ${ }^{12}$, сопроводив их ценными комментариями и воспоминаниями [Trubetzkoy, Jakobson, 1985] (русское издание: [Трубецкой, Якобсон, 2004]) $)^{13}$. Между прочим, одно из писем Якобсона Трубецкому (от 6 апреля 1929 г.) содержит свидетельство о преобразовании ПЛК в научное объединение нового типа:

9 На необходимость публикации этого письма указывал Патрик Серио в рецензии на издание Й. Томана [Sériot, 1997, p. 346].

${ }^{10}$ Аббревиатура этого собрания (RJP = Roman Jakobson Papers) осталась нерасшифрованной в списке сокращений на с. 757-758. Полная архивная ссылка: Massachusetts Institute of Technology. Libraries. Department of Distinctive Collections. MC-0072 (Roman Jakobson Papers).

11 Включено и франкоязычное письмо Якобсона к Шарлю Балли от 17 марта 1931 г. (c. 522-523; cp. [Toman, 1994, p. 147]).

12 При участии Хенрика Ба́рана, Омри Ронена и Марты Тейлор.

${ }^{13}$ Сами письма в обоих изданиях напечатаны по-русски. В оригинальном издании научный аппарат дан на английском языке, в издании 2004 г. - в переводе на русский. 
«Вдруг всему инициативному ядру кружка пришла мысль, что кружок как парламент мнений, как свободная трибуна для дискуссий - пережиток, и что кружок должен быть преобразован в тесно-сплоченную по научной идеологии группу. <..> Этот процесс ныне очень успешно осуществляется. В кружке образовалась своего рода инициативная комиссия в составе Матезиуса, очень способного лингвиста Гавранка, Мукаржовского, Трнки и меня. Эта перелицовка кружка буквально воодушевила его членов <..>. Кружок захватил в свои руки лингвистическую секцию подготовительного комитета съезда славистов, проведя туда пять членов из семи. В семичленной литературной секции два члена кружка. Кружок составил список принципиальных проблем, о которых предложено высказаться желающим членам съезда. <..> Кружок готовит тезисы по всем этим вопросам» [Trubetzkoy, Jakobson, 1985, p. 122, footnote 4; Трубецкой, Якобсон, 2004, с. 126, примеч. 4] (см.: [Toman, 1991, p. 20-23]).

В результате были напечатаны - на двух языках, по-французски и по-чешски, - знаменитые Тезисы ПЛК. Французский текст был опубликован в первом выпуске «Трудов ПЛК» (1929), а чешский текст (вместе с французским) представлен на Первом Международном съезде славистов в Праге 6-13 октября 1929 г. Такие коллективные тезисы«декларации» Якобсон считал наиболее эффективным способом научного самоопределения «в момент мирового радикального пересмотра всенаучной методологии» [Якобсон, 1979, с. 563]. По воспоминаниям ученого секретаря ПЛК Йозефа Вахека, Тезисы «стали результатом многочисленных заседаний специально назначенной для этой цели комиссии, в которую обычно входили Матезиус, Якобсон, Гавранек, Трнка и Мукаржовский, а иногда и некоторые другие члены Кружка, чаще всего М. Вейнгарт <..> . Встречи продолжались в течение нескольких месяцев и проходили так: каждый раздел Тезисов подготавливался одним из членов комиссии и затем совместно обсуждался всеми ее членами. Таким образом, окончательную редакцию <Тезисов > можно назвать подлинно коллективным произведением» [Vachek, 1983, p. 287].

Окончательная редакция Тезисов была утверждена на заседании ПЛК 28 июня 1929 г. В них сформулирована широкая программа изучения языков, литератур и фольклора славянских народов структурно-лингвистическими методами. 31 октября 1929 г. в газетной заметке о Съезде славистов Якобсон применил заимствованный у психологов термин «структурализм» к новой методологии исследования языка и словесности. Согласно автору заметки, новая структуральная славистика пришла на смену двум предшествующим стадиям развития этой дисциплины - романтическому панславизму и позитивистской славистике [Jakobson, 1929]. 
Одновременно с этим statement'oм на чешском языке Якобсон употребил тот же термин по-немецки в статье «Über die heutigen Voraussetzungen der russischen Slavistik», напечатанной в октябрьском номере «Slavische Rundschau» [Гаспаров, Автономова, 1999, с. 334]. На каком из двух языков этот термин был использован раньше, неясно.

Ряд материалов «Пражской школы в корреспонденции» отражает события сложнейшего периода в межвоенной истории Центральной Европы - годы Второй Чехословацкой Республики и последовавшей затем германской оккупации Чехии (протектората). После Мюнхенского соглашения 1938 г. два немца - богемист Ойген Риппль и музыковед Густав Беккинг - вышли из состава ПЛК. Письмо Беккинга от 17 декабря 1938 г. с просьбой о прекращении членства (№5) написано по-немецки и содержит формальную мотивировку самоотвода: невладение чешским, который стал основным языком заседаний Кружка (с. 54). Аналогичное письмо Риппля от 9 декабря 1938 г. (№ 217) написано по-чешски и не содержит никакой формальной мотивировки (с. 279) ${ }^{14}$. Дальнейшая судьба двух ученых, внесших значительный вклад в развитие Пражской школы ${ }^{15}$, описана в обсуждаемой книге лишь отчасти. В апреле 1939 г. Беккинг вступил в NSDAP, в годы протектората занимал должность декана философского факультета Немецкого университета в Праге, а 9 мая 1945 г. - в день освобождения Праги от нацистов был, как считается, растерзан разъяренной толпой на пражских улицах [Fuchs, 2001]. Риппль был членом пронацистской Партии судетских немцев (Sudetendeutsche Partei), а затем вступил в NSDAP. Продолжал работать в Немецком университете, в 1941 г. получил должность ординарного профессора чешской и славянской филологии. Умер при невыясненных обстоятельствах в своей квартире в Праге 10 мая 1945 г. [Kraft, 2001; Ehlers, 2003].

К сожалению, в сборник не включены такие яркие свидетельства эпохи, как письмо Якобсона в Исполнительный комитет (Výbor) Пражского лингвистического кружка от 24 февраля 1939 г. о снятии с себя полномочий заместителя председателя ПЛК. Письмо написано за три недели до прихода нацистов в Прагу и за два месяца до вынужденного бегства Якобсона из оккупированной Чехии (опубликовано: [Toman, 1994, p. 194]). Последний советский паспорт был выдан Якобсону в Праге 19 декабря 1934 г. (действителен до 19 декабря

\footnotetext{
${ }^{14}$ Оба письма ранее публиковались в издании [Toman, 1994, p. 192-193]. Факсимиле письма Беккинга см. в книге [Ehlers, 2005, p. 430].

15 Так, доклад Беккинга «Musikologie und Sprachwissenschaft» («Музыковедение и языкознание»), прочитанный на заседании ПЛК 30 ноября 1932 г., Якобсон в письме Отокару Фишеру от 16 декабря 1932 г. (№ 69) называет «эпохальным» («ероchální») (c. 140).
} 
1935 г.) [Steiner, 2018, p. 82; Стайнер, 2018, с. 21], а 21 октября 1937 г. Якобсон получил чехословацкое гражданство, что позволило ему занять профессорскую должность в Брненском университете на постоянной основе. Однако еще до ввода немецких войск в Чехию 15 марта 1939 г. и установления германского протектората Якобсон как еврей был вынужден покинуть университет (официально он был отправлен в отпуск на неопределенный срок). В марте 1939 г. Студенческое общество философского факультета Брненского университета выпустило прощальную брошюру «Romanu Jakobsonovi - pozdrav a díkůvzdání» («Роману Якобсону - приветствие и благодарность»), в которой ректор Арне Новак напечатал статью «Tvưrčí znalec staročeského básnictví» («Знаток древнечешской литературы») [Малевич, 1993, с. 85; Малевич, 2007, с. 115]. В ноябре 1939 г. все чешские университеты были закрыты по приказу нацистских властей. Для Якобсона «наступили годы вынужденных бездомных блужданий из страны в страну» [Якобсон, Поморска, 1982, с. 27]. В апреле 1939 г. Якобсон с женой (Сватавой ПирковойЯкобсон), опасаясь ареста, в течение месяца нелегально жили в Праге в ожидании визы в Данию. Три статьи Якобсона, вышедшие до конца 1939 г. в оккупированной Праге (о происхождении формулы «Собака Калин царь», о вкладе средневековой чешской культуры в общецерковнославянскую и о влиянии старочешской словесности на старопольскую), были напечатаны под «скандинавским» псевдонимом «Олаф Янсен» (Olaf Jansen). Вскоре после «Мюнхенского сговора», предопределившего дальнейшую судьбу Чехословакии, т.е. с октября 1938 г., Якобсон начал просить датских коллег об университетском приглашении, которое было получено в апреле 1939 г. В 20-х числах апреля 1939 г. он прибыл проездом через Берлин в столицу Дании как приглашенный профессор Копенгагенского университета [Fischer-Jørgensen, 1997; Ба́ран, 2017, с. 453]. С этой даты и близкой по времени эмиграции Рене Веллека можно отсчитывать время «Пражской школы в изгнании» - много лет спустя это понятие ввел Любомир Долежел, чешский лингвист и теоретик литературы, признанный глава чешской эмигрантской филологии, уехавший в Канаду после пражских событий 1968 г. [Doležel, 1996].

Не вошло в сборник переписки пражцев и заявление Матезиуса в Исполком ПЛК от 20 июня 1940 г. о том, что он «не является евреем в смысле § 1 государственного распоряжения № 136/1940 из Сборника законов и распоряжений» («že nejsem židem ve smyslu § 1 vládního nařízení čísl. 136/1940 Sb<írky> z<ákonů> a n<ařízení>») [Toman, 1994, p. 219]. О важности этих документов писали рецензенты томановского издания, где были напечатаны обсуждаемые письма [Hlavsa, Daneš, 1996, p. 245-246; Thomas, 1997, p. 125]. Государственное распоряжение 
136/1940 от 4 июля 1939 г., опубликованное в «Сборнике законов и распоряжений протектората Богемии и Моравии» за 1940 г. (нем.: «Sammlung der Gesetze und Verordnungen des Protektorats Böhmen und Mähren», чеш.: «Sbírka zákonů a nařízení Protektorátu Čechy a Morava»), запрещало евреям занимать общественные должности. Первая статья распоряжения устанавливала определение «еврея» в формулировке, соответствующей так называемым «нюрнбергским расовым законам», а именно статье пятой «Первого распоряжения к Закону о гражданстве Рейха» («Erste Verordnung zum Reichsbürgergesetz») от 14 ноября 1935 г. [Trial, p. 488 (Документ 998-PS. c. 76); Tauchen, 2011, p. 185-186, 189; Drgo, 2014, p. 318-321; Tokárová, 2019, p. 94-95]. В соответствии с распоряжением 136/1940 Матезиус не мог бы занимать должность председателя Кружка, если бы был евреем, и должен был представить соответствующие документы, чтобы продолжать руководить Кружком.

Отдельный интерес представляют письма, отражающие процессы и события в Чехословакии после Второй мировой войны. Так, обращает на себя внимание переписка Александра Исаченко с Богуславом Гавранком и Богумилом Трнкой за 1945-1949 гг., свидетельствующая о безуспешных попытках опубликовать в Чехословакии «Altkirchenslavische Grammatik» Николая Трубецкого. Книга первоначально планировалась к выходу в качестве IX тома «Travaux du Cercle Linguistique de Prague», но в результате вышла только в 1954 г. в Вене.

Историков, изучающих перипетии взаимоотношений между наукой и официальной идеологией, несомненно, заинтересуют документы, связанные с антиструктуралистской кампанией 1951 г. в журнале «Tvorba» (см. [Chobotová, 2011; Pešek, 2013]) и участием в ней Яна Мукаржовского (см. [Červenka, 1991, p. 5; Kříž, 2014, p. 144-145, 148; Sládek, 2015a, p. 289-348; Steiner, 2019]). Таковы письма Мукаржовскому от Йиндржиха Гонцля (27 ноября 1951 г.) и Феликса Водички (12 ноября 1951 г.). Объемное представление об идеологическом и стилистическом контексте антиструктуралистских дискуссий дает письмо, направленное кафедрой романистики и англистики Брненского университета Богуславу Гавранку (13 апреля 1951 г.), с обширными приложениями - тезисами доклада Франтишка Травничка «Структурализм в языкознании» («Strukturalismus v jazykovědě») и разъяснительной запиской Йозефа Вахека от 6 апреля 1951 г. Все указанные материалы 1951 г. (№ 91, 313, 381; с. 152, 403-415, 472) опубликованы впервые. Травничек, бывший структуралист и член ПЛК [Čermák, Poeta, Čermák, 2012, p. 399], стал автором погромной статьи «Структурализм - враг нашего языкознания» [Trávníček, 1951] и вскоре - новым ректором Брненского университета. 
Члены ПЛК были специалистами в различных областях знания, поэтому подготовка переписки потребовала от комментаторов немалых профессиональных усилий и массы библиографических разысканий. Вряд ли стоит пенять на то, что какие-то детали остались неучтенными или непрокомментированными. Задача комментария - предоставить читателю минимум, необходимый для понимания текста, и она, по большому счету, в обсуждаемом издании выполнена. Позволю себе, тем не менее, несколько фактографических замечаний, преимущественно связанных с русскоязычными авторами и персонажами публикуемых писем.

21 июля 1936 г. Якобсон пишет Бему (письмо № 9): «Маха выделяет не только Дельвига и Пушкина, но и Даля» (с. 57) ${ }^{16}$. В записных книжках великого чешского романтика Карела Гинека Махи имеются выписки из русских писателей: Дельвига, Пушкина и Даля [Toman, 1994, p. 187, note 7]. Но Даль для Махи, умершего в 1836 г., - еще не «языковед и лексикограф» (с. 58, примеч. 4 к письму № 9), а писатель-романтик и отчасти этнограф. Даль дебютировал как прозаик в 1830 г., в 1832 г. опубликовал обработанные им «Русские сказки», а в 1833-1836 гг. вышли первые три тома его «Былей и небылиц». Эти его книги, как и позднейшие художественные произведения, печатались под псевдонимом «Казак Владимир Луганский». Первая лингвистическая работа Даля была напечатана только в 1852 г., а первый выпуск первого тома его знаменитого «Толкового словаря живого великорусского языка» вышел в 1861 г.

6 октября 1960 г. Богатырев пишет Гавранку из Братиславы (письмо № 18): «Каждый день работаю в Академии и университетской библиотеке, где собираю материал для своих статей. Собрал материал для главы <sic!> “Язык песни”» (с. 67). Речь идет об одной из двух работ, изобилующих словацким и чешским материалом: либо о статье Богатырева «О языке славянских народных песен в его отношении к диалектной речи» [Богатырев, 1962], либо о его статье-докладе «Добавочные гласные в народной песне и их функции (О языке славянских народных песен и его отношении к разговорной речи)» [Богатырев, 1963].

В указателе не учтено упоминание Константина Петровича Богатырева (переводчика-германиста, погибшего в 1976 г., предположительно в результате провокации КГБ, сына П.Г. Богатырева) в письме Тамары Богатыревой Богуславу и Здене Гавранкам (12 сентября 1971 г.), извещающем о смерти Петра Григорьевича Богатырева (№ 27; с. 79).

\footnotetext{
${ }^{16}$ Письмо (№ 9 в пражском издании) ранее публиковалось в [Toman, 1994].
} 
В послевоенном письме Чижевскому (№ 45) Якобсон, рассказывая о своем издании «Слова о полку Игореве» [Grégoire, Jakobson, Szeftel, 1948], особо отмечает «жесточайший разнос Мазона по всем пунктам» (c. 100 $)^{17}$. Сборник «La geste du prince Igor', épopée russe du douzième siècle» («Слово о полку Игореве, русский эпос XII в.») был подготовлен Якобсоном совместно с его коллегами по нью-йоркской Свободной школе высших исследований (École Libre des Hautes Études, ELHE): византинистом Анри Грегуаром и историком Марком Шефтелем ${ }^{18}$. Издание, о котором говорит Якобсон, указано в комментарии (с. 102, примеч. 12 к письму № 45), но, наверное, стоило бы специально указать, что в случае с Андре Мазоном речь идет об одном из важнейших вопросов русской медиевистики - вопросе о подлинности «Слова», в полемике по поводу которой Мазон представлял сторону «скептиков» (см. [Mazon, 1940] и др. печатные выступления). В 125-страничной статье «L'authenticité du Slovo» («Подлинность “Слова”»), включенной в сборник, Якобсон подробно разобрал все аргументы Мазона и опроверг их, доказывая древность языка и поэтики памятника с опорой на историко-лингвистические сведения и десятки древнерусских параллелей к «темным местам» в его тексте. В той же книге Якобсон опубликовал критическую реконструкцию текста «Слова», в которой предложил новое словоделение и собственный перевод древнерусского текста на современный русский язык. 11 апреля 1948 г. Сергей Карцевский писал Якобсону: «Ты мастерски высек Мазона. Теперь, когда у него задница должна быть вспухшей, на чем будет он сидеть, напр., на Лингвист <ическом> Конгрессе в Париже? <..> Интересно было бы посмотреть на физиономию Мазона, когда он читал эту книгу» [Карцевский, Якобсон, 1999, с. 179-180]. В 2004-2008 гг. выводы Якобсона подтвердил и дополнил А.А. Зализняк, который окончательно доказал аутентичность языка «Слова о полку Игореве» и пришел к выводу, что вероятность подделки близка к нулю.

ELHE была своеобразным французским «университетом в изгнании», открывшимся в Нью-Йорке 14 февраля 1942 г. при поддержке Фонда Рокфеллера и Французского национального комитета Шарля де Голля («Свободной Франции») [Rutkoff, Scott, 1983]. Якобсон занял в ELHE должность профессора общей лингвистики на филологическом факультете

\footnotetext{
${ }^{17}$ Редакторский перевод, кажется, не отражает энергичной эспрессивности якобсоновской самохарактеристики: «tvrdá kritika Mazona ve všech bodech» (c. 101). Жесточайший (superlativus elativus) - это жестче, чем просто $t v r d \dot{y}$, а разнос - это гораздо резче, чем проcто kritika.

${ }^{18}$ Между прочим, Шефтель считается основным прототипом набоковского Пнина.
} 
(Faculté des Lettres), a c 1943 г. также должность профессора славянской филологии в Институте восточной и славянской филологии и истории (Institut de Philologie et d'Histoire Orientale et Slave) [Toman, 1995, p. 245-250, 298-299]. В Нью-Йорке Якобсон сотрудничал с чехословацким правительством в изгнании и заявлял о себе как о «представителе пражской школы лингвистики и истории литературы» [Там же, p. 247]. В ELHE работали выдающиеся гуманитарии, уехавшие из Франции и Бельгии под угрозой преследования (в том числе по причине еврейского происхождения), и в их числе великий французский антрополог Клод Леви-Стросс. Его общение с Якобсоном в эти годы во многом предопределило пути развития структурализма в Западной Европе и Северной Америке. Под непосредственным влиянием лекций Якобсона Леви-Стросс начал использовать методы описания языковых структур для описания социальных структур - таких, как системы родства. Основополагающая статья Леви-Стросса «L'Analyse structurale en linguistique et en anthropologie» («Структурный анализ в лингвистике и в антропологии») со ссылками на работы Якобсона, послужившие методологическими образцами для автора статьи, была напечатана в первом номере журнала Нью-йоркского кружка «Word» (1945). Одним из основателей Нью-йоркского лингвистического кружка ${ }^{19}$, начавшего работу в октябре 1943 г., стал, наряду с другими профессорами ELHE, Якобсон, который занимал пост заместителя председателя Кружка до 1949 г., т.е. вплоть до своего отъезда из Нью-Йорка в Гарвард. Это был третий и последний лингвистический кружок, основанный Якобсоном.

Лекции, прочитанные Якобсоном в 1942-1943 гг., вышли в 1976 г. в Париже под заглавием «Six leçons sur le son et le sens» («Шесть лекций о звуке и смысле») с предисловием Леви-Стросса [Jakobson, 1976]. Русский перевод Е.Э. Разлоговой, озаглавленый «Звук и значение», напечатан в томе «Избранных работ» Якобсона, вышедшем в «прогрессовской» серии «Языковеды мира» под редакцией В.А. Звегинцева с предисловием Вяч. Вс. Иванова [Якобсон, 1985]. В связи с темой многолетнего научного общения Якобсона с Леви-Строссом укажу, что совсем недавно была издана их переписка, продолжавшаяся с 1942 г. до смерти Якобсона в 1982 г. [Jakobson, Lévi-Strauss, 2018]. Насколько мне известно, она еще не прорецензирована в российских изданиях. Со своим французским другом и коллегой Якобсон переписывался, разумеется, по-французски: это был его первый и любимый иностранный

${ }^{19}$ The Linguistic Circle of New York; с 1969 г. - The International Linguistic Association (ILA). 
язык. В первый раз Якобсон использовал французский в международном общении, взяв на себя роль переводчика на встречах русских футуристов с Филиппо Томмазо Маринетти в 1914 г. [Якобсон, 2012, с. 37$]^{20}$.

Вернемся в межвоенную Чехословакию. В трех письмах Якобсона к Дурново за 1925-1926 гг. (№ 53, 54 и 59) фигурирует некий Яша. В первом письме Якобсон рассказывает: «Яша занимается диалектологией: по рецепту Моск<овской> Диал<ектологической $>$ Ком $<$ иссии $>$ изучает местный говор у женского населения» (с. 118). Комментарий к этому месту лаконичен: «Jaša nezjištěn» (c. 119, примеч. 2 к письму № 53). Между тем загадочный Яша есть, несомненно, Яков Григорьевич Гурьян (1899 - не позже 1945), друг Якобсона и Григория Осиповича Винокура. Его имя оставлено без комментария и в издании [Toman, 1994], где эти письма были опубликованы впервые. В письме Якобсону от 18 октября 1925 г. (из Москвы в Прагу) Винокур передает Гурьяну привет и также называет Яшей [Гиндин, 1996а, с. 68 (текст письма) и 73, примеч. 43 (комментарий)].

О гибели Я.Г. Гурьяна Якобсон сообщал Чижевскому в вышеупомянутом послевоенном письме (№ 45; с. 100). В комментарии к этому письму и в указателе к сборнику Гурьян вслед за томановским изданием [Toman, 1994, p. 225, note 7] назван Яковом Герасимовичем (c. 102, примеч. 3 к письму № 45, и с. 790). Однако, по данным С.И. Гиндина, отца Якова Гурьяна звали Григорий Давидович ${ }^{21}$. Действительно, Герасим - весьма необычное имя для российского еврея в эти годы. Сведения о том, что Гурьян носил отчество «Герасимович», восходят к Якобсону, который летом 1956 г. рассказывал В.Д. Дувакину о том, что он (Якобсон) и Гурьян были соавторами Маяковского по антибелогвардейской и эстетически хулиганской «Советской азбуке» ${ }^{22}$ : «Хорошо помню, как Маяковский просил принять участие в работе над

${ }^{20}$ Известно, что «учителем французского языка у Якобсона был Генрих Эдмундович Тастевен (1881-1915), литературный и художественный критик, переводчик с французского языка и секретарь журнала “Золотое руно” (1907-1909)» [Сорокина, 2016, с. 79].

21 «Григорий Давидович и Евгения Григорьевна Гурьяны и их сыновья Анатолий и Яков, московская семья, очень близкая молодым Винокуру, Богатыреву и Якобсону. Жили в том же доме в Лубянском проезде, что и Якобсон и его родители. Впоследствии стали свойственниками Винокуру» [Гиндин, 1996b, с. 23, примеч. 10].

22 Во время выступления в Доме комсомола Красной Пресни на вечере, посвященном двадцатилетию деятельности, 25 марта 1930 г. Маяковский рассказывал: «Она была написана как пародия на старую, была такая порнографическая азбука. <...> Она была написана для армейского употребления. Там были такие остроты, которые для салонов не очень годятся, но которые для окопов шли очень хорошо. <...> Эту книгу... я принес печатать в Центропечать. Там сидела не вычищенная еще машинистка одна, которая с большой злобой мне сказала: “Лучше я потеряю всякую работу, но эту гадость я переписывать не буду”» [Маяковский, 1959, с. 428-429] (см.: [Шапир, 1996, с. 364-365]). 
азбукой меня и приятеля нашего... Якова Герасимовича Гурьяна» (MIT. Roman Jakobson Papers. Box 41, folder 2; цит. по: [Шапир, 1996, с. 389, примеч. 25]). Можно предположить, что мы имеем дело либо с оговоркой Якобсона, либо с нередким в послереволюционном быту фактом русско-еврейской двуименности. Так, имя и отчество самого Якобсона в студенческом деле 1914 г. и студенческом билете Московского университета 1916-1917 гг. - Роман Иосель-Берович, тогда как в послереволюционных документах он - Роман Иосифович [Сорокина, 2016, с. 74, 81], а в быту - Роман Осипович. Я.Г. Гурьян присутствовал в качестве «гостя» на многих заседаниях ПЛК, проходивших в 1932-1936 гг. [Čermák, Poeta, Čermák, 2012, p. 124-224 (по указ.)]. В протоколах заседаний его имя обозначено инициалом («J. Gurian»), и в указателе к изданию документов ПЛК оно не расшифровано [Там же, p. 761]. Сопоставление всех перечисленных писем и документов позволяет восполнить эту лакуну.

О том, что Гурьян погиб в немецком концлагере, так же как и младший брат Якобсона Михаил, мы знаем из переписки Якобсона с Сергеем Карцевским, не вошедшей в обсуждаемое издание. В письме от 7 мая 1948 г., написанном (точнее, напечатанном) по-английски (в начале письма адресант извиняется за то, что у него нет машинки с кириллическим шрифтом), Якобсон рассказывает: «Јaša Gurian perished in a German concentration camp. Also my youngest brother». «Печально слышать, что Яша погиб, как и Твой брат», - отвечает по-русски Карцевский 18 июня 1948 г. [Карцевский, Якобсон, 1999, с. 181, 182]. М.О. Якобсон, проживавший в эмиграции во Франции, был депортирован из Ниццы в 1944 г. и, вероятно, тоже погиб в немецком концлагере.

Еще в одном письме Якобсона к Дурново (1925 г.), вошедшем в пражский сборник (№ 57), не прокомментированы ${ }^{23}$ имена сразу двух Томашевских, которых Якобсон характеризует так: «коммунист Томашевский (ученик Бодуэна, не смешивайте с Б. Томашевским, опоязовцем)» (c. 124). Первый - это иранист Всеволод Брониславович Томашевский (1891-1927), которого Ян (Иван Александрович) Бодуэн де Куртенэ в письме к Василию Алексеевичу Богородицкому от 24 ноября (7 декабря) 1915 г. называет в числе своих главных последователей [Леонтьев, 1990, с. 373; Петров, 2013]. Второй - стиховед и пушкинист Борис Викторович Томашевский (1890-1957), член Опояза и МЛК. В комментарии к этому письму Б.В. Томашевский несправедливо не включен в число участников Опояза (с. 127, примеч. 4 к письму № 57). Кроме того, Б.В. Томашевский не попал, с отсылкой к этим страницам

${ }^{23}$ Так же, как и в [Toman, 1994], где письма Якобсона к Дурново публиковались ранее. 
(124-127), в указатель, где он все-таки присутствует в связи с упоминаниями в других письмах. В этом же письме Якобсона фигурирует «жена $<$ Дмитрия Николаевича> Ушакова» (с. 125-126), не названная по имени и тоже не попавшая в комментарий и указатель. Это Александра Николаевна Ушакова (урожд. Мисюра, 1880-1954).

В письме Якобсона к Дурново от 4 февраля 1927 г. (№ 66) вслед

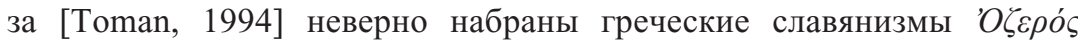

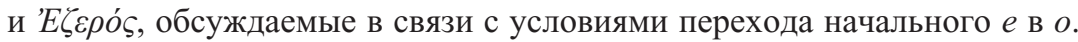
Якобсон, ссылаясь на Макса Фасмера, указывает, что вторая форма старше, а первая происходит из нее «путем стяжения, согласно закону греческой фонетики» (с. 135) - cp. [Vasmer, 1941, p. 107].

Переписка Якобсона с Отокаром Фишером за 1936 и январь 1937 г. в значительной степени посвящена фишеровым переводам пушкинских драм, составившим заключительный том 4-томного издания сочинений Пушкина, которое печаталось под редакцией Якобсона и Альфреда Бема к 100-летию со дня смерти поэта. Переписка Якобсона с Фишером (переводчиком «Бориса Годунова» и «Маленьких трагедий») и с Йозефом Горой (переводчиком «Евгения Онегина» и «Цыган»), со свидетельствами об их совместной работе над переводами, публиковалась ранее в чешском томе избранных писем Якобсона [Jakobson, 1997] (см. также: [Малевич, 2007, с. 112-113]). Письмо Якобсона Фишеру от 21 января 1937 г. (№ 79), посвященное переводу «Бориса Годунова», написано, как и все прочие письма Якобсона Фишеру, по-чешски, но в нем есть одна вставка по-русски: «Ро přečtení korektur tleskal jsem, jako kdysi Puškin po ukončení Godunova, a křičel ${ }^{24}$ : Ай-да Фишер, молодец!» (с. 145). Русская фраза требует комментария (особенно для нерусскоязычных читателей). Это аллюзия на известное письмо Пушкина князю Петру Андреевичу Вяземскому (около 7 ноября 1825 г.), в котором Пушкин хвастается: «...трагедія моя кончена, я перечелъ ее въ слухъ, одинъ, и билъ въ ладоши и кричалъ, ай-да Пушкинъ, ай-да сукинъ сынъ!» [Пушкин, 1926, с. 167]. В качестве послесловий к отдельным томам чешского собрания сочинений Пушкина напечатаны заметки Якобсона «По поводу лирических стихотворений Пушкина», «По поводу “Евгения Онегина”» и «Об отзвуках народной поэзии у Пушкина». К этому же времени относится статья «Socha v symbolice Puškinově» («Статуя в символике Пушкина»), более известная под позднейшим авторским заглавием «The Statue in Puškin’s Poetic Mythology» («Статуя в поэтической мифологии Пушкина»). Она основана на докладе

24 'По прочтении корректур зааплодировал, как Пушкин по окончании «Годунова», и вскричал: ...’. 
Якобсона «K Puškinově symbolice» («К пушкинской символике»), прочитанном в ПЛК 8 февраля 1937 г. Цикл пушкиноведческих работ Якобсона вышел отдельным изданием в английском переводе Дж. Бурбанка в 1975 г. [Jakobson, 1975], а по-русски только в 1987 г., в переводе Н.В. Перцова с английского в составе якобсоновских «Работ по поэтике» - второго сборника трудов Якобсона из серии «Языковеды мира», вышедшего под редакцией М.Л. Гаспарова с предисловием Вяч. Вс. Иванова [Якобсон, 1987].

В письме Гавранку от 24 марта 1957 г. (№ 126) Исаченко пишет, что «jsem se v Lipsku seznámil s prof. S.M. Kljujevym, který přednáší ruskou literatúru na Karel Marxové Univerzitě» ${ }^{25}$ (с. 181). В указателе к обсуждаемой книге Клюев фигурирует без имени и отчества (приведены только инициалы). Вот некоторые сведения об этом человеке: Степан Макарович Клюев, кандидат филологических наук (1951), специалист по творчеству А.В. Кольцова, впоследствии профессор Московского государственного педагогического института им. В.И. Ленина.

В письме Вахеку от 28 апреля 1943 г. (№ 279) Матезиус говорит о своем ученике Ярославе Альбрехте (1911-1979): «Те̌ší mne, Že Albrecht pokračuje ve svých článcích o škole Otakara Hostinského» ${ }^{26}$ (c. 356). В комментарии сказано: «Статьи Альбрехта о школе Отакара Гостинского не найдены» (с. 357, примеч. 5 к письму № 279). Не может ли, однако, иметься в виду вторая часть статьи Я. Альбрехта «Dvořákovy opery a česká kritika hudební» [Albrecht, 1941, № 10], значительная часть которой посвящена Гостинскому и его критической школе? Немало внимания Гостинскому уделено и в статье [Albrecht, 1942/1943], которая обсуждается в письме Матезиуса Вахеку от 21 декабря 1943 г. (см. с. 369 и 371 , примеч. 10 к письму № 287).

В заключение, возвращаясь к вопросу об академической мобильности (как добровольной, так и вынужденной) и ее роли в развитии научной мысли, укажу, что теме научной эмиграции посвящено несколько разделов еще одной недавней книги о Пражской школе - это книга Ондржея Сладека «Метаморфозы пражской школы структурной поэтики» [Sládek, 2015b]. Первое поколение «Пражской школы в изгнании» представлено в ней именами Романа Якобсона (1896-1982) и Рене Веллека (1903-1995). Среди представителей послевоенной миграционной волны - ученик Якобсона Ладислав Матейка (1919-2012), эмигрировавший после коммунистического госпереворота в Чехословакии в 1948 г.

25 'В Лейпциге я познакомился с проф. С.М. Клюевым, который преподает русскую литературу в Университете имени Карла Маркса'.

26 'Я рад, что Альбрехт продолжает писать в своих статьях о школе Отакара Гостинского'. 
и ставший издателем прославленной славистической серии Мичиганского университета (Энн Арбор), а также три исследователя, покинувшие страну после вторжения войск Варшавского договора в 1968 г.: Любомир Долежел (1922-2017), Моймир Грыгар (род. 1928) и Кветослав Хватик (1930-2012). Вот как Сладек описывает влияние Пражской школы на мировое литературоведение ${ }^{27}$. Встреча Якобсона со чешскими коллегами в 1926 г. привела к созданию ПЛК. Затем Пражская школа создала в эмиграции несколько других подобных локусов. Одним из них стал Нью-Йорк - место встречи Якобсона с Леви-Строссом. Последующее возвращение Леви-Стросса во Францию дало толчок к возникновению и развитию французского структурализма. Формирование «рецептивной эстетики» Констанцской школы, в котором принципиальная роль принадлежала Хватику, и создание нарратологии Долежелом (а также его вклад в изучение семантики вымышленных миров) - это следующие этапы пражского воздействия на «западную» теорию литературы и культуры. Если воспользоваться метафорой Якобсона, можно сказать, что экспорт центральноевропейских ценностей в конце концов состоялся ${ }^{28}$.

\section{Библиографический список / References}

Автономова, 2009 - Автономова Н.С. Открытая структура: Якобсон Бахтин - Лотман - Гаспаров. М., 2009. [Avtonomova N.S. Otkrytaya struktura: Yakobson - Bakhtin - Lotman - Gasparov [An open structure: Jakobson - Bakhtin Lotman - Gasparov]. Moscow, 2009. (In Russ.)]

Ба́ран, 2017 - Ба́ран Х. Хроника основных событий жизни и творчества Р.О. Якобсона // Роман Осипович Якобсон. М., 2017. С. 446-465. (Сер. «Философия России первой половины XX века»). [Baran H. Chronicle of the main events in the life and work of R.O. Jakobson. Roman Osipovich Jakobson. Moscow, 2017. Pp. 446-465. (In Russ.)]

Богатырев, 1962 - Богатырев П.Г. О языке славянских народных песен в его отношении к диалектной речи // Вопросы языкознания. 1962. № 3. С. 75-86. [Bogatyrev P.G. On the language of Slavic folk songs and its relation to dialectal speech. Voprosy yazykoznaniya. 1962. № 3. Pp. 75-86. (In Russ.)]

Богатырев, 1963 - Богатырев П.Г. Добавочные гласные в народной песне и их функции (О языке славянских народных песен и его отношении к разговорной речи) // Славянское языкознание: V Международный съезд славистов, София, сентябрь 1963: Доклады советской делегации. М., 1963. С. 349-398. [Bogatyrev P.G. Inserted vowels in folk songs and their functions (On the language of Slavic folk songs and its attitude to spoken language). Slavyanskoe yazykoznanie: V Mezhdunarodnyi s"ezd slavistov, Sofiya, sentyabr' 1963: Doklady sovetskoy delegatsii. Moscow, 1963. Pp. 349-398. (In Russ.)]

27 Дополнительные соображения см. в моей рецензионной статье: [Pilshchikov, 2019].

${ }^{28}$ Uurimistööd on finantseerinud Eesti Teadusagentuur (PRG319). 
Гаспаров, Автономова, 1999 - Гаспаров М.Л., Автономова Н.С. Якобсон, славистика и евразийство: две конъюнктуры, 1929-1953 // Роман Якобсон: Тексты, документы, исследования. М., 1999. С. 334-340. [Gasparov M.L., Avtonomova N.S. Jakobson, Slavistics and the Eurasian movement: two moments of opportunity, 1929-1953. Roman Jakobson: Texts, Documents, Studies. Moscow, 1999. Рp. 334-340. (In Russ.)]

Гиндин, 1996а - Гиндин С.И. Эпизод эпистолярной полемики Г.О. Винокура и Р.О. Якобсона // Изв. РАН. Сер. лит. и яз. 1996. Т. 55. № 6. С. 60-74. [Gindin S.I. An episode from the epistolary polemic between G.O. Vinokur and R.O. Jakobson. Bulletin of the Russian Academy of Sciences: Literature and Language. 1996. Vol. 55. № 6. Pp. 60-74. (In Russ.)]

Гиндин, 1996b - Гиндин С.И. «Рома пишет из Праги...» (Письмо Г.О. Винокура П.Г. Богатыреву) // Материалы Международного конгресса «100 лет Р.О. Якобсону». Москва, 18-23 декабря 1996 года. М., 1996. С. 19-23. [Gindin S.I. "Roman writes from Prague..." (G.O. Vinokur's letter to P.G. Bogatyrev). Contributions to the International Congress "Roman Jakobson Centennial”. Moscow, 18-23 December 1996. Moscow, 1996. Pp. 19-23.]

Гиндин, 1999 - Гиндин С.И. К истории создания и воприятия статьи «О поколении, растратившем своих поэтов»: Письмо Р.О. Якобсона Х. МакЛейну // Роман Якобсон: Тексты, документы, исследования. М., 1999. С. 161-166. [Gindin S.I. Toward the history of the creation and reception of the article "On a Generation that Squandered its Poets": R.O. Jakobson's letter to Hugh McLean. Roman Jakobson: Texts, Documents, Studies. Moscow, 1999. Pp. 161-166. (In Russ.)]

Гланц, Пильщиков, 2017 - Гланц Т., Пильщиков И. Русские формалисты как научное сообщество // Эпоха «остранения»: Русский формализм и современное гуманитарное знание. М., 2017. С. 85-100. [Glanc T., Pilshchikov I. The Russian Formalists as a scholarly community. Epokha "ostraneniya": Russkii formalizm i sovremennoe gumanitarnoe znanie. Moscow, 2017. Pp. 85-100. (In Russ.)]

Иванов, 1975 - Иванов Вяч. Вс. Знаковые системы научного поведения // Научно-техническая информация. Сер. 2: Научные процессы и системы. 1975. № 9. C. 3-9. [Ivanov Vyach.V. Sign systems of scientific behavior. Nauchnotekhnicheskaya informatsiya. Seriia 2: Informatsionnye protsessy $i$ sistemy. 1975. № 9. Pp. 3-9. (In Russ.)]

Карцевский, Якобсон, 1999 - Переписка С.И. Карцевского и Р.О. Якобсона / Вступ. ст., публ. и примеч. Х. Ба́рана, Е.В. Душечкиной // Роман Якобсон: Тексты, документы, исследования. М., 1999. С. 175-191. [S.I. Kartsevsky’s correspondence with R.O. Jacobson. Introduction, publication and notes by H. Baran and E.V. Dushechkina. Roman Jakobson: Texts, Documents, Studies. Moscow, 1999. Pp. 175-191. (In Russ.)]

Леонтьев, 1990 - Леонтьев А.А. Петербургская (Ленинградская) школа в языкознании // Лингвистический энциклопедический словарь. М., 1990. С. 373-374. [Leontiev A.A. The Petersburg (Leningrad) school of linguistics. Lingvisticheskii enciklopedicheskii slovar'. Moscow, 1990. Pp. 373-374. (In Russ.)]

Малевич, 1993 - Малевич О.М. Роман Якобсон в Чехословакии // Евреи в культуре русского зарубежья. Иерусалим, 1993. Вып. II. С. 65-90. [Malevich O.M. Roman Jakobson in Czechoslovakia. Evrei v kul'ture russkogo zarubezh'ya. Jerusalem, 1993. Vol. II. Pp. 65-90. (In Russ.)] 
Малевич, 2007 - Малевич О.М. Роман Якобсон по-чешски // Русская литература. 2007. № 1. C. 104-117. [Malevich O.M. Roman Jakobson in Czech. Russkaya literatura. 2007. № 1. Pp. 104-117. (In Russ.)]

Марченко, 2016-Марченко Т.В. Россика на страницах «Slavische Rundschau» // Литературный факт. 2016. № 1/2. C. 142-178. [Rossica on the pages of "Slavische Rundschau”. Literaturnyi fakt. 2016. № 1/2. Pp. 142-178. (In Russ.)]

Маяковский, 1959 - Маяковский В.В. Полн. собр. Соч.: В 13 т. М., 1959. T. 12. [Mayakovsky V.V. Complete Works. In 13 vols. Vol. 12. Moscow, 1959. (In Russ.)]

Петров, 2013 - Петров В.В. «Большой была его работа и яркой - жизнь его...». В.Б. Томашевский: первый коммунист во главе Ленинградского университета, 1926-1927 гг. // Клио. 2013. № 10 (82). С. 109-111. [Petrov V.V. “Great was his work and bright his life...". V.B. Tomashevsky: The first communist at the head of Leningrad University, 1926-1927. Clio. 2013. № 10 (82). Pp. 109-111. (In Russ.)]

Пушкин, 1926 - Пушкин А.С. Письма / Под ред. и с примеч. Б.Л. Модзалевского. М.; Л., 1926. Т. 1. [Pushkin A.S. Letters. Ed., with notes, by B.L. Modzalevsky. Moscow; Leningrad, 1926. Vol. 1. (In Russ.)]

Серио, 1999 - Серио П. Лингвистика географов и география лингвистов: Р.О. Якобсон и П.Н. Савицкий // Роман Якобсон: Тексты, документы, исследования. М., 1999. С. 348-353. [Sériot P. The linguistics of geographers and the geography of linguists: R.O. Jakobson and P.N. Savitsky. Roman Jakobson: Texts, Documents, Studies. Moscow, 1999. Pp. 348-353. (In Russ.)]

Стайнер, 2018 - Стайнер П. «Which side are you on, boy?»: Роман Якобсон в Праге межвоенного периода // Слово.ру: балтийский акцент. 2018. Т. 9. № 1. C. 13-28. [Steiner P. "Which side are you on, boy?" Roman Jakobson in interwar Prague. Slovo.Ru: Baltic Accent. 2018. Vol. 9. № 1. Pp. 13-28. (In Russ.)]

Сорокина, 2016 - Сорокина М.Ю. Эмигрант № 1017: Роман Якобсон в московских архивах // Ежегодник Дома русского зарубежья им. А. Солженицына, 2016. М., 2016. С. 72-92. [Sorokina M.Yu. Émigré \#1017: Roman Jakobson in the Moscow archives. Ezhegodnik Doma russkogo zarubezh'ya im. A. Solzhenitsyna, 2016. Moscow, 2016. Pp. 72-92. (In Russ.)]

Тиханов, 2002 - Тиханов Г. Почему современная теория литературы возникла в Центральной и Восточной Европе / Авториз. пер. с англ. С. Силаковой // Новое литературное обозрение. 2002. № 53. С. 75-88. [Tihanov G. Why did modern literary theory originate in Central and Eastern Europe? Novoe literaturnoe obozrenie. 2002. № 53. Рp. 75-88. (In Russ.)]

Трубецкой, Якобсон, 2004 - Письма и заметки Н.С. Трубецкого. Подгот. к изд. Р. Якобсон. М., 2004. [N.S. Trubetzkoy's letters and notes. Prepared for publication by R. Jakobson. Moscow, 2004. (In Russ.)]

Шапир, 1996 - Шапир М.И. Из истории «пародического балладного стиха»: 2. Вставало солнце ало // Анти-мир русской культуры: Язык. Фольклор. Литеpaтура. M., 1996. C. 355-404. [Shapir M.I. From the history of the "parodic ballad verse": 2. Vstavalo solntse alo. In: Anti-mir russkoy kul'tury: Yazyk; Fol'klor; Literatura. Moscow, 1996. Pp. 355-404. (In Russ.)]

Эйхенбаум, 1927 - Эйхенбаум Б.М. Литература и литературный быт // На литературном посту. 1927. № 9. С. 47-52. [Eikhenbaum B.M. Literature and literary environment. Na literaturnom postu. 1927. № 9. Pp. 47-52.] 
Якобсон, 1931 - Якобсон Р. К характеристике евразийского языкового союза. Париж, 1931. [Jakobson R. K kharakteristike evraziyskogo yazykovogo soyuza [Characteristics of the Eurasian Sprachbund]. Paris, 1931. (In Russ.)]

Якобсон, 1979 - Якобсон Р. Юрий Тынянов в Праге [1974] // Jakobson R. Selected Writings. The Hague; Paris; New York, 1979. Vol. V: On Verse, Its Masters and Explorers. Pp. 560-568. [Jakobson R. Yuri Tynianov in Prague [1974]. R. Jakobson. Selected Writings. Vol. V: On Verse, Its Masters and Explorers. The Hague; Paris; New York, 1979. Pp. 560-568. (In Russ.)]

Якобсон, Поморска, 1982 - Якобсон Р., Поморска К. Беседы. Иерусалим, 1982. [Jakobson R., Pomorska K. Besedy [Dialogues]. Jerusalem, 1982.]

Якобсон, 1985 - Якобсон Р. Избранные работы. М., 1985. [Jakobson R. Izbrannye raboty [Selected essays]. Moscow, 1985. (In Russ.)]

Якобсон, 1987 - Якобсон Р. Работы по поэтике. M., 1987. [Jakobson R. Raboty po poetike [Essays in poetics]. Moscow, 1987. (In Russ.)]

Якобсон, 1996 - Якобсон Р.О. Московский лингвистический кружок / Подгот. текста, публ., [вступ. ст. и примеч.] М.И. Шапира // Philologica. 1996. T. 3. № 5/7. C. 365-368. [Jakobson R.O. The Moscow Linguistic Circle. Ed., with an introduction and notes by M.I. Shapir. Philologica. 1996. Vol. 3. № 5/7. Pp. 361-380. (In Russ.)]

Якобсон, 2012 - Роман Якобсон. Будетлянин науки: Воспоминания, письма, статьи, стихи, проза / Сост., подгот. текста, вступ. ст. и коммент. Б. Янгфельдта. M., 2012. [Roman Yakobson. Budetlyanin nauki: Vospominaniya, pisma, stati, stikhi, proza [Roman Jakobson: A futurist in scholarship: Memoirs, letters, essays, poems, prose]. Ed., with an introduction and notes by B. Jangfeldt. Moscow, 2012. (In Russ.)]

Albrecht, 1941 - Albrecht J. Dvořákovy opery a česká kritika hudební [Dvořák’s operas and Czech music criticism]. Řád. 1941. Vol. VII. № 9. S. 481-490; № 10. Pp. 529-541.

Albrecht, 1942/1943 - Albrecht J. O shakespearské slavnosti z roku 1864 [The Shakespeare Festival of 1864]. Český časopis filologický. 1942/1943. Vol. I. Pp. 31-36.

Chobotová, 2011 - Chobotová K. Le structuralisme pragois vu par le marxisme officiel en Tchécoslovaquie. Cahiers de l'ILSL. № 31: Langue(s). Langage(s). Histoire(s). E. Velmezova (éd.). Lausanne, 2011. Pp. 99-118.

Čermák, Poeta, Čermák, 2012 - Pražský lingvistický kroužek v dokumentech [The Prague Linguistic Circle in documents]. P. Čermák, C. Poeta, J. Čermák (eds.). Praha, 2012.

Červenka, 1991 - Červenka M. Jana Mukařovského rozchod se strukturalismem [Jan Mukařovský’s break with structuralism]. Tvar. 1991. № 36. Pp. 1, 4-5.

Doležel, 1996 - Doležel L. Pražská škola v exilu [The Prague School in exile]. Světová literárněvědná bohemistika. Sv. 2: Úvahy a studie o české literatuře. Materiály z 1. kongresu světové literárněvědné bohemistiky. Praha 28.-30. června 1995. Praha, 1996. Pp. 506-511.

Drgo, 2014 - Drgo J. Legislatívne vymedzenie pojmu Žid v II. Česko-Slovenskej republike, I. Slovenskej republike a Protektoráte Čechy a Morava v rokoch 1938-1942 [Legislative definition of the term "Jew" in the second Czechoslovak Republic, first Slovak Republic and Protectorate of Bohemia and Moravia (1938-1942)]. Historický časopis. 2014. Vol. 62. № 2. Pp. 303-323. 
Ehlers, 2003 - Ehlers K.-H. Prager Deutsche im Prager Zirkel: Ein Überblick. Prager strukturalismus: Methodologische Grundlagen. Heidelberg, 2003. Pp. 49-77.

Ehlers, 2005 - Ehlers K.-H. Strukturalismus in der deutschen Sprachwissenschaft: Die Rezeption der Prager Schule zwischen 1926 und 1945. Berlin; New York, 2005.

Fischer-Jørgensen, 1997 - Fischer-Jørgensen E. Roman Jakobson and Denmark. Acta Linguistica Hafniensia. 1997. Vol. 29. Pp. 13-28.

Fuchs, 2001 - Fuchs T. Gustav W. Becking (1894-1945) Musikwissenschaftler: Im Spannungsfeld zwischen traditioneller Geisteswissenschaft und nationaler Ideengeschichte. Prager Professoren 1938-1948: zwischen Wissenschaft und Politik. Essen, 2001. Pp. 221-236.

Greenblatt, 2009 - Greenblatt S. A Mobility Studies Manifesto. Cultural Mobility: A Manifesto. S. Greenblatt (ed.). Cambridge, 2009. Pp. 250-253.

Grégoire, Jakobson, Szeftel, 1948 - La Geste du prince Igor', épopée russe du douzième siècle. Texte établi, traduit et commenté sous la direction d'H. Grégoire, de R. Jakobson et de M. Szeftel. New York, 1948.

Haupt, Kocka, 2010 - Comparative and Transnational History: Central European Approaches and New Perspectives. H.-G. Haupt, J. Kocka (eds.). Oxford; New York, 2010.

Havránková, Petkevič, 2014 - Pražská škola v korespondenci: Dopisy z let 1924-1989 [The Prague School in correspondence: Letters 1924-1989]. M. Havránková, V. Petkevič (eds.). Praha, 2014.

Hlavsa, Daneš, 1996 - Hlavsa Z., Daneš F. Jindřich Toman a Pražský lingvistický kroužek [Jindřich Toman and the Prague Linguistic Circle]. Slovo a Slovesnost. 1996. Vol. 57. № 3. Pp. 241-246.

Jakobson, 1929 - Jakobson R. Romantické všeslovanství - nová slavistika [Romantic panslavism - new slavistics]. Čin. 31.10.1929. Pp. 10-12.

Jakobson, 1934 - Jakobson R. O předpokladech pražské lingvistické školy [The premises of the Prague Linguistic School]. Index. 1934. Vol. 6. № 1. Pp. 6-9.

Jakobson, 1971 - Jakobson R. An Example of Migratory Terms and Institutional Models (On the Fiftieth Anniversary of the Moscow Linguistic Circle) [1965]. R. Jakobson. Selected Writings. Vol. II: Word and Language. The Hague; Paris, 1971. Pp. 527-538.

Jakobson, 1975 - Jakobson R. Puškin and His Sculptural Myth. Trans. and ed. by J. Burbank. The Hague; Paris, 1975.

Jakobson, 1976 - Jakobson R. Six leçons sur le son et le sens. Préface de C. LéviStrauss. Paris, 1976.

Jakobson, 1997 - Jakobson R. Z korespondence [From His Correspondence]. A. Morávková (ed.). Praha, 1997.

Jakobson, Lévi-Strauss, 2018 - Jakobson R., Lévi-Strauss C. Correspondance 1942-1982. Préfacé, édité et annoté par E. Loyer et P. Maniglier. Paris, 2018.

Kraft, 2001 - Kraft D. Eugen Rippl (1888-1945) Slawist: «Für eine wissenschaftliche Publikation darf es keine Verwässerung und Verfärbung geben...»: Ein Fachmann auf dem Gebiet der Sondersprachenforschung. Prager Professoren 1938-1948: zwischen Wissenschaft und Politik. Essen, 2001. Pp. 323-349.

Křŕž, 2014 - Křŕž M. Boj o strukturalismus: Archeologie českého literárněvědného strukturalismu [Contest for structuralism. The archeology of Czech literary structuralism]. Olomouc, 2014.

Mazon, 1940 - Mazon A. Le Slovo d'Igor. Paris, 1940. 
Pešek, 2013 - Pešek O. Le structuralisme fonctionnel pragois face au stalinisme: bouleversements, soubresauts et paradoxes. Echo des études romanes. 2013. Vol. 9. № 2. Pp. 5-20.

Pilščikov, 2015 - Pilščikov I. V šesti jazycích: Nad knihou Pražská škola $v$ korespondenci [In six languages: Reflections on the book The Prague School in Correspondence]. Trans. A. Machoninová. Česká literatura. 2015. Vol. 63. № 4. Pp. 573-584.

Pilshchikov, 2019 - Pilshchikov I. The Prague School on a Global Scale: a Coup d'œil from the East. Slovo a slovesnost. 2019. Vol. 80. № 3. Pp. 215-228.

Pilshchikov, Trunin, 2016 - Pilshchikov I., Trunin M. The Tartu-Moscow School of Semiotics: A transnational perspective. Sign Systems Studies. 2016. Vol. 44. № 3. Pp. 368-401.

Rutkoff, Scott, 1983 - Rutkoff P.M., Scott W.B. The French in New York: Resistance and Structure. Social Research. 1983. Vol. 50. № 1. Pp. 185-214.

Said, 2000 - Said E.W. Travelling Theory reconsidered. E.W. Said. Reflections on Exile and Other Essays. Cambridge, Mass., 2000. Pp. 436-452.

Sériot, 1997 - Sériot P. [Rec. ad op.]: Letters and Other Materials from the Moscow and Prague Linguistic Circles, 1912-1945. J. Toman (ed.). Ann Arbor, 1994. Russian Linguistics. 1997. Vol. 21. № 3. Pp. 345-346.

Sériot, 1999 - Sériot P. Structure et totalité: Les origines intellectuelles du structuralisme en Europe centrale et orientale. Paris, 1999.

Sládek, 2015a - Sládek O. Jan Mukařovský: Život a dílo [Jan Mukařovský: Life and work]. Brno, 2015.

Sládek, 2015b - Sládek O. The Metamorphoses of Prague School Structural Poetics. Munich, 2015.

Steiner, 1982 - Steiner P. The Roots of Structuralist Esthetics. The Prague School. Selected Writings, 1929-1946. P. Steiner (ed.). Austin, Texas, 1982. Pp. 174-219.

Steiner, 2018 - Steiner P. Which Side Are You on? Roman Jakobson in Interwar Prague. Roman Jakobson: linguistica e poetica. S. Sini, M. Castagneto, E. Esposito (eds.). Milano, 2018. Pp. 75-86.

Steiner, 2019 - Steiner P. From Structuralism to Marxism (and Back?): Jan Mukařovský 1945-1963. Studies in East European Thought. 2019. Vol. 71. In print. Springer Online First Publication: https://doi.org/10.1007/s11212-019-09338-1

Tauchen, 2011 - Tauchen J. The Status of Jews in Labor Relationships in the Protectorate of Bohemia and Moravia. Miscellanea historico-iuridica. 2011. Vol. 10. № 1. Pp. 183-190.

Tihanov, 2004 - Tihanov G. Why Did Modern Literary Theory Originate in Central and Eastern Europe? (And Why is It Now Dead?). Common Knowledge. 2004. Vol. 10. № 1. Pp. 61-81.

Tihanov, 2019 - Tihanov G. The Birth and Death of Literary Theory: Regimes of Relevance in Russia and Beyond. Stanford, 2019.

Thomas, 1997 - Thomas G. [Rec. ad op.]: Letters and Other Materials from the Moscow and Prague Linguistic Circles, 1912-1945. J. Toman (ed.). Ann Arbor, 1994. The Slavonic and East European Review. 1997. Vol. 75. № 1. Pp. 124-126.

Tokárová, 2019 - Tokárová Z. Legislative Interventions into the Creation of Local: Political elites as an instrument of anti-Jewish policy during the Holocaust (A comparative view). Mesto a dejiny. 2019. Vol. 8. № 1. Pp. 80-109. 
Toman, 1991 - Toman J. Linguistics in Society: Notes on the Emergence of the Prague Circle. Journal of Comparative Literature and Aesthetics. 1991. Vol. 14. № 1/2. Pp. 15-26.

Toman, 1994 - Letters and other materials from the Moscow and Prague Linguistic Circles, 1912-1945. J. Toman (ed.). Ann Arbor, 1994.

Toman, 1995 - Toman J. The magic of a common language: Jakobson, Mathesius, Trubetzkoy, and the Prague Linguistic Circle. Cambridge, Mass.; London, 1995.

Trávníček, 1951 - Trávníček F. Strukturalismus - nepřítel naší jazykovědy [Structuralism: Enemy of our linguistics]. Tvorba. 1951. Vol. 20. № 37. Pp. 866-869.

Trial - Trial of the major war criminals before the International Military Tribunal, Nuremberg, 14 November 1945 - 1 October 1946. Official text. English edition. Nuremberg, 1947. Vol. XXVI: Documents and other material in evidence. Numbers 405-PS to 1063 (d)-PS.

Trubetzkoy, Jakobson, 1985 - N.S. Trubetzkoy's Letters and Notes. Prepared for publication by R. Jakobson. Berlin; New York; Amsterdam, 1985.

Ustinov, 2018 - Ustinov A. Roman Jakobson and the Generation «that Squandered its Poets». Roman Jakobson: linguistica e poetica. S. Sini, M. Castagneto, E. Esposito (eds.). Milano, 2018. Pp. 105-121.

Vachek, 1983 - Vachek J. The Czech editor's postscript. Praguiana: Some Basic and Less Known Aspects of the Prague Linguistic School. Amsterdam; Philadelphia, 1983. Pp. 275-302.

Vasmer, 1941 - Vasmer M. Die Slaven in Griechenland. Berlin, 1941.

Werner, Zimmermann, 2006 - Werner M., Zimmermann B. Beyond Comparison: Histoire croisée and the Challenge of Reflexivity. History and Theory. 2006. Vol. 45. № 1. Pp. $30-50$.

Статья поступила в редакцию 10.09.2019

The article was received on 10.09.2019

\section{O6 авторе / About the author}

Пильщиков Игорь Алексеевич - доктор филологических наук; профессор кафедры славянских, восточноевропейских и евразийских языков и культур, Университет Калифорнии, Лос-Анджелес; ведущий научный сотрудник Института мировой культуры, Московский государственный университет имени М.В. Ломоносова; старший научный сотрудник Института гуманитарных наук, Таллинский университет, Эстония

Igor A. Pilshchikov - Dr. Phil. Hab.; Professor at the Department of Slavic, East European and Eurasian Languages and Cultures, University of California, Los Angeles, USA; Lead Researcher at the Institute of World Culture, Lomonosov Moscow State University; Senior Researcher at the Institute of Humanities, Tallinn University, Estonia

ORCID: https://orcid.org/0000-0003-0153-6598

E-mail: pilshch@mail.ru 